\title{
COMPARATIVE STUDY OF HELIUM BUBBLE FORMATION IN Cr-Fe-Ni-Mn HIGH-ENTROPY ALLOY AND 18Cr10NiTi STEEL AFTER IRRADIATION AND POST-IRRADIATION ANNEALING
}

\author{
A.S. Kalchenko, S.A. Karpov, I.E. Kopanets, M.A. Tikhonovsky, G.D. Tolstolutskaya \\ National Science Center "Kharkov Institute of Physics and Technology", \\ Kharkiv, Ukraine \\ E-mail: karpofff@kipt.kharkov.ua
}

High entropy alloys (HEAs) are considered for applications in nuclear reactors due to their promising mechanical properties, corrosion and radiation resistance. In order to understand the irradiation effects in HEAs and to demonstrate their potential advantages over conventional austenitic stainless steels, we performed helium ion irradiation experiments with $20 \mathrm{Cr}-40 \mathrm{Fe}-20 \mathrm{Ni}-20 \mathrm{Mn}$ high-entropy alloy and $18 \mathrm{Cr} 10 \mathrm{NiTi}$ steel under an identical condition. Both alloys have been irradiated to a dose of 4.8 displacement per atom (dpa) and a helium concentration of 11.7 at. $\%$ at room temperature. After subsequent annealing at $500{ }^{\circ} \mathrm{C}$ the microstructure evolution of irradiated materials was examined. The irradiation promotes the formation of a high density of bubbles in HEA and steel. Comparison of parameters of helium porosity in these materials has been done.

PACS: 61.72.CC, 68.55. LN

\section{INTRODUCTION}

A severe problem in the fission and fusion irradiation environment is production of a certain amount of transmutation elements through reactions of $(n, p)$ and $(n, \alpha)$ in the bulk of structural materials. The high energy alpha particles can induce volume swelling and high temperature $\mathrm{He}$ embrittlement by enhancing the void nucleation and growth process due to low solubility of helium in metals $[1,2]$.

The study of He-ions irradiation effects on materials, including the formation and evolution of irradiation damage defects and the diffusion and aggregation of helium ions, has become one of the top challenges in fusion field [3]. During migration of the vacancies and helium atoms, the grain boundaries are more likely to be the nucleation sites of helium bubble whose volume are closely related to the irradiation temperature [2].

Very dense fine helium bubbles are formed at low temperatures by continuously absorption of helium atoms, while large bubbles are produced at high temperatures. The increasing of the volume of helium bubbles will lead to the blistering and the repeated exfoliation of the sample surface, which will seriously degrade the physical properties of materials and reduce their service life [4].

A necessary task for develop new nuclear reactors with safe, sustainable and efficient properties is the research of structural materials with superior performance in the extreme environment of high temperature, high stress and intense irradiation damage.

Recently, in addition to traditional materials, a new type of materials with excellent properties - high entropy alloys (HEAs) has been proposed [5]. HEAs are defined as solid solution alloys that contain more than four principal elements in equal or near equal atomic percent (at.\%), in which the high configurational entropy of mixing reaches its maximum [6]. There are also many other similar names, like multi-component alloys, equiatomic ratio alloys and multi-principalelements alloys.
Extensive studies have revealed the excellent properties of concentrated solid solution alloys, including microstructure stability under ion irradiations, a good corrosion resistance and the ability to maintain good mechanical properties over a wide-range temperature [7, 8]. However, the He behavior in HEAs, including the formation and growth of He bubbles, is still questionable.

In the present study, a non-cobalt $20 \mathrm{Cr}-40 \mathrm{Fe}-20 \mathrm{Ni}$ $20 \mathrm{Mn}$ (mass \%) high entropy alloy has been investigated. Cobalt is unfavorable element for nuclear applications due to high neutron transmutation-induced radioactivity.

The aim of this work is to study the microstructure evolution of this material irradiated at room temperature to a dose of $4.8 \mathrm{dpa}$ and a helium concentration of 11.7 at. $\%$ and subsequently annealed at $500{ }^{\circ} \mathrm{C}$. Annealing was used as method for investigation of exposure of the short-term high thermal flux on the first wall material of fusion power reactor. Comparison of the parameters of helium porosity in $20 \mathrm{Cr}-40 \mathrm{Fe}-20 \mathrm{Ni}$ $20 \mathrm{Mn}$ and $18 \mathrm{Cr} 10 \mathrm{NiTi}$ steel irradiated and annealed at the same conditions was made.

\section{EXPERIMENTAL DETAILS}

High entropy alloy with the nominal compositions (in mass \%) of $20 \mathrm{Cr}-40 \mathrm{Fe}-20 \mathrm{Mn}-20 \mathrm{Ni}$ was produced by arc melting in a high-purity argon in a water-cooled copper mould. The purity of alloying elements was above $99.9 \%$. To ensure chemical homogeneity, the ingots were flipped over and re-melted a least 5 times. The alloy was studied after homogenization. Homogenization annealing of ingots was carried out at $1050{ }^{\circ} \mathrm{C}$ and lasted for $24 \mathrm{~h}$.

Alloys were subjected to thermomechanical treatment (TMT) that consisted in deformation of the rolling at room temperature from $6 \mathrm{~mm}$ to $0.2 \mathrm{~mm}$ with intermediate annealing at $1100{ }^{\circ} \mathrm{C}$ for $3 \mathrm{~h}$. Finishing annealing after decreasing sample thickness to $0.2 \mathrm{~mm}$ was carried out at $1100{ }^{\circ} \mathrm{C}$ for $1 \mathrm{~h}$ [9]. 
$18 \mathrm{Cr} 10 \mathrm{NiTi}$ steel investigated in this study was solution annealed at $1050{ }^{\circ} \mathrm{C}$ for $30 \mathrm{~min}$.

Samples for TEM studies were prepared as disks of $3 \mathrm{~mm}$ in diameter. Thin foils were obtained by mechanical thinning of the disks down to $130 \mu \mathrm{m}$ followed by electropolishing and short-term annealing.

The samples were implanted with $20 \mathrm{keV} \mathrm{He}^{+}$ions to a dose of $1 \cdot 10^{21} \mathrm{~m}^{-2}$. Irradiations were performed with irradiation facility in accelerating-measuring system "ESU-2" [10]. The ion flux was $1 \cdot 10^{18} \mathrm{He} /\left(\mathrm{m}^{2} \cdot \mathrm{s}\right)$. Ion implantation was carried out at normal ion incidence. The temperature of the sample did not exceed $25^{\circ} \mathrm{C}$ during irradiation.

The evolution of microstructure was investigated after post-implantation annealing at $500{ }^{\circ} \mathrm{C}$ for $10 \mathrm{~min}$. Specimens were thinned for TEM examination by jetelectropolishing with a solution of $5 \%$ perchloric acid and $95 \%$ ethanol from back side of the sample until perforation.

Ion stopping distribution for $20 \mathrm{keV}$ helium ions and irradiation damages (in dpa) have been calculated with the software The Stopping and Range of Ions in Matter (SRIM 2008) [11]. The dpa calculations are based on a displacement energy threshold of $40 \mathrm{eV}$ and on the Kinchin-Pease formalism and Stoller recommendations [12] (Fig. 1). The thickness of the foils was not measured directly but assumed to be in the range of $100 \mathrm{~nm}$ according to their brightness in electron microscope.

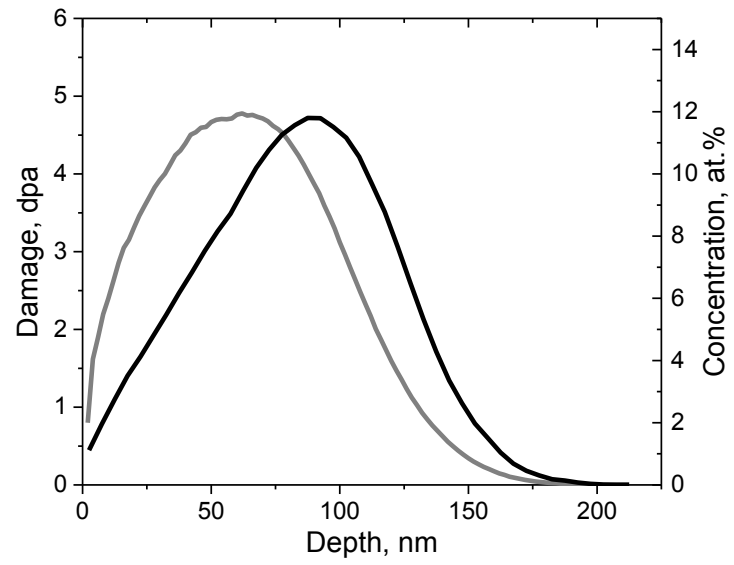

Fig. 1. Calculated profiles of damages and concentrations of $20 \mathrm{keV} \mathrm{He}$ ions in 20Cr-40Fe-20Mn-

20Ni alloy irradiated to a dose of $1 \cdot 10^{21} \mathrm{~m}^{-2}$

The microstructure of the alloys was studied by electron microscope JEM-2100. Generally, small He bubbles are observed at under-focused condition to increase the imaging contrast. The average bubble size was measured from more than 150 bubbles in each sample.

\section{RESULTS AND DISCUSSIONS}

Fig. 2 shows typical initial microstructure of $18 \mathrm{Cr} 10 \mathrm{NiTi}$ steel and $20 \mathrm{Cr}-40 \mathrm{Fe}-20 \mathrm{Mn}-20 \mathrm{Ni}$ high entropy alloy.

The microstructure of unirradiated $18 \mathrm{Cr} 10 \mathrm{NiTi}$ steel consisted mostly of austenite grains (size $\sim 30 \mu \mathrm{m}$ ), but small crystallites of $\delta$-ferrite were also observed at a volume fraction of $2 \ldots 3 \%$. Annealing twins, precipitates (carbides and titanium carbonitrides) and dislocations $\left(\sim 10^{8} \mathrm{~cm}^{-2}\right)$ were seen in austenitic grains.

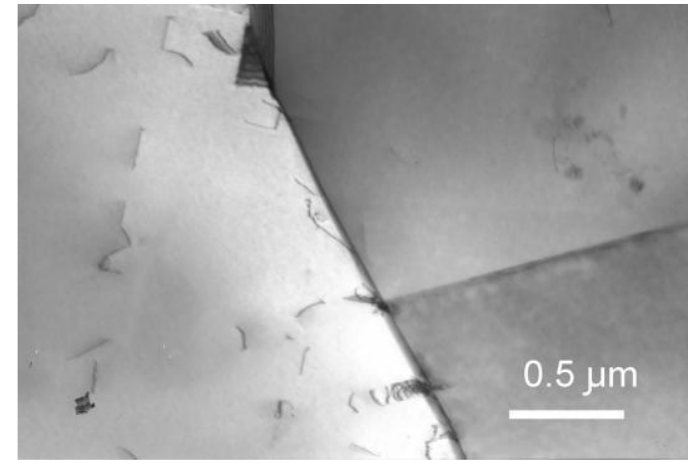

$a$

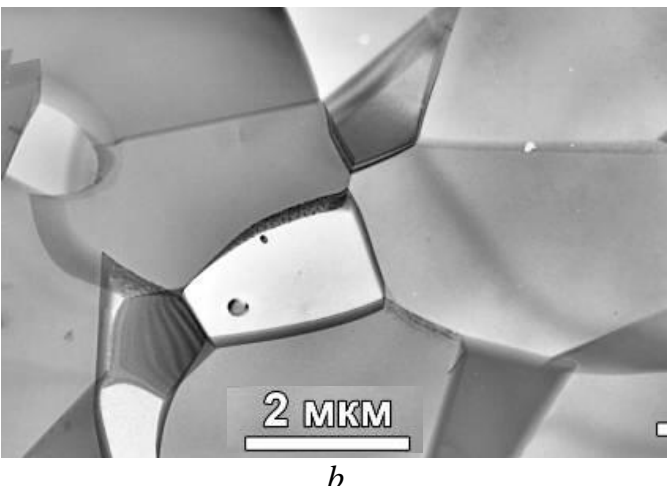

Fig. 2. The initial microstructure of $18 \mathrm{Cr} 10 \mathrm{NiTi}$ steel (a), 20Cr-40Fe-20Mn-20Ni high-entropy alloy (b)

The results of the study of the structure of HEA alloy are described in [9]. According to X-ray analysis as-cast alloy is single-phase with FCC crystal lattice. After TMT and final heat treatment at $850{ }^{\circ} \mathrm{C}$, the alloy is single-phase also. Measured by means of EDS and nominal compositions of HEA alloy and $18 \mathrm{Cr} 10 \mathrm{NiTi}$ steel are presented in Table 1.

Table 1

Nominal and measured materials composition (mass \%)

\begin{tabular}{|c|cccc|c|c|c|}
\hline Sample & Fe & $\mathbf{C r}$ & $\mathbf{N i}$ & $\mathbf{M n}$ & $\mathbf{T i}$ & $\mathbf{S i}$ \\
\hline CrFeNiMn & - & - & - & - & - & - \\
Nominal & 40 & 20 & 20 & 20 & - & - \\
Measured & 41.23 & 19.82 & 19.42 & 19.18 & - & 0.35 \\
18Cr10NiTi & - & - & - & - & - & - \\
Nominal & Bal. & $17-19$ & $9-11$ & 2 & $0.4-1$ & 0.8 \\
Measured & 68.1 & 17.9 & 10.8 & 1.75 & 0.71 & 0.74 \\
\hline
\end{tabular}

Fig. 3 shows the microstructure evolution of $20 \mathrm{Cr}-$ $40 \mathrm{Fe}-20 \mathrm{Mn}-20 \mathrm{Ni}$ high entropy alloy and $18 \mathrm{Cr} 10 \mathrm{NiTi}$ steel after He irradiation and subsequent annealing at $500{ }^{\circ} \mathrm{C}$ for $10 \mathrm{~min}$ in high vacuum. Irradiation leads to the microstructural defects development, which induced by nuclear collisions, as well as to the formation of helium bubbles.

Detailed TEM characterization reveals that $\mathrm{He}$ bubbles in $18 \mathrm{Cr} 10 \mathrm{NiTi}$ steel and $\mathrm{Fe}-\mathrm{Co}-\mathrm{Cr}-\mathrm{Ni}$ alloy exhibit different morphology and density.

The kinetics of helium porosity development at annealing of $18 \mathrm{Cr} 10 \mathrm{NiTi}$ stainless steel irradiated with $20 \mathrm{keV}$ helium ions at room temperature have been investigated in [13]. TEM examination of irradiated 
steel was conducted in the annealing temperature range from $T_{\text {room }}$ to $1140{ }^{\circ} \mathrm{C}$. At a dose of $1 \cdot 10^{21} \mathrm{~m}^{-2}$, bubbles were observed immediately after irradiation at $T_{\text {room }}$. At annealing, the average diameter of the bubbles varies from $\sim 2 \mathrm{~nm}$ at $T_{\text {room }}$ to $10 \ldots 20 \mathrm{~nm}$ at $T_{\text {ann }}=1140{ }^{\circ} \mathrm{C}$. In the low-temperature region of annealing from $T_{\text {room }}$ to $500{ }^{\circ} \mathrm{C}$ the average diameter and the density of bubbles virtually does not change.

As shown in Fig. 3,a, in the case of 18Cr10NiTi, very small and sparse spherical helium bubbles with

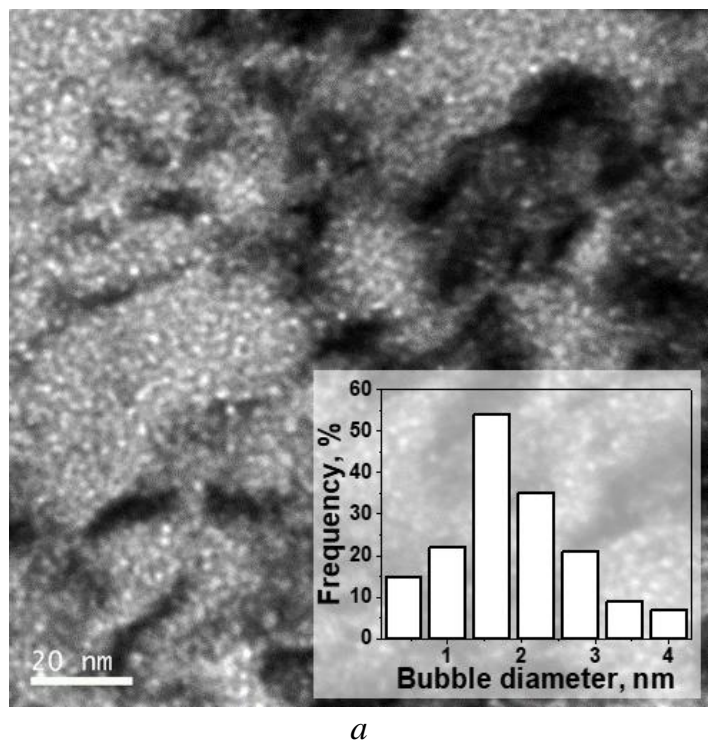

average diameter of $\sim 1.6 \mathrm{~nm}$ and a density of $1.0 \cdot 10^{24} \mathrm{~m}^{-3}$ have been observed.

In contrast, numerous bubbles with average diameter of $\leq 1.0 \mathrm{~nm}$ were observed in irradiated Fe-Co$\mathrm{Cr}-\mathrm{Ni}$ alloy (see Fig. 3,b). TEM observation was conducted from over-focus to under-focus in several samples. The bubble density and diameter in both alloys, the uncertainties for the size and density are summarized in Table 2.

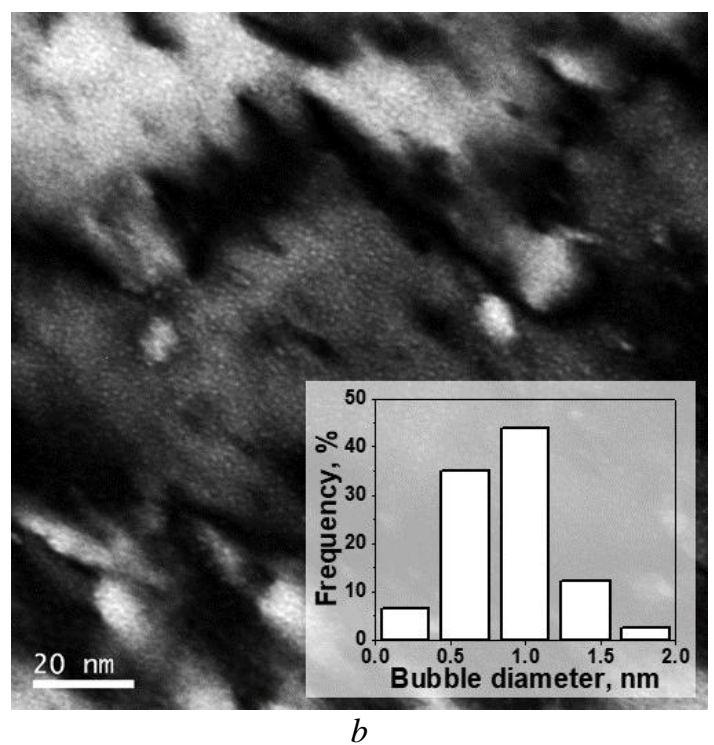

Fig. 3. The morphology and distribution of He bubbles in irradiated and subsequently annealed 18Cr10NiTi steel (a) and 20Cr-40Fe-20Mn-20Ni high entropy alloy (b)

Table 2

Helium bubbles size and density for 18Cr10NiTi steel and 20Cr-40Fe-20Mn-20Ni alloy after irradiation and $500{ }^{\circ} \mathrm{C}$ annealing for $10 \mathrm{~min}$

\begin{tabular}{|c|c|c|c|c|c|c|}
\hline Sample & $\begin{array}{c}\text { Helium } \\
\text { fluence, } \mathrm{He}^{+} / \mathrm{m}^{2}\end{array}$ & $\begin{array}{c}\text { Irradiation } \\
\text { damage, dpa }\end{array}$ & $\begin{array}{c}\text { He concentration } \\
\text { at projected depth, } \\
\text { at. \% }\end{array}$ & $\begin{array}{c}\text { Mean } \\
\text { diameter, } \\
\mathrm{nm}\end{array}$ & $\begin{array}{c}\text { Number } \\
\text { density, } \\
10^{24} \mathrm{~m}^{-3}\end{array}$ & $\begin{array}{c}\text { Swelling, } \\
\%\end{array}$ \\
\hline FeCrNiMn & $1 \cdot 10^{21}$ & 4.8 & 11.7 & $0.9 \pm 0.3$ & $3.1 \pm 0.5$ & 0.15 \\
\hline 18Cr10NiTi & $1 \cdot 10^{21}$ & 4.8 & 11.7 & $1.6 \pm 0.4$ & $1.0 \pm 0.2$ & 0.32 \\
\hline
\end{tabular}

As can be seen from Table 1, the helium bubbles size in CrFeNiMn alloy is smaller than that in $18 \mathrm{Cr} 10 \mathrm{NiTi}$ steel, while the number density approximately 3 times larger. Calculated values of helium-associated swelling were evaluated to be 0.15 and $0.32 \%$ for $\mathrm{HEA}$ and $18 \mathrm{Cr} 10 \mathrm{NiTi}$, respectively, suggesting that the helium bubble formation is suppressed in the HEA. The suppression of bubble formation may be related to the HEAs' intrinsic properties, i.e. severe large lattice distortion and chemical disorder.

It is known that the extremely low solubility of helium can exacerbate precipitation of He into clusters or bubbles at sinks which causes property degradation of structural materials. However, the different bubble behavior between studied materials is observed.

Yan et al. [14] have demonstrated that high temperature annealing leads to a formation of large bubbles and cavities (hundreds of nanometers) in $\mathrm{Ni}$, while in $\mathrm{Fe}-\mathrm{Co}-\mathrm{Cr}-\mathrm{Ni}$ bubble growth was limited. Authors explained these observations by low helium diffusivity in $\mathrm{Fe}-\mathrm{Co}-\mathrm{Cr}-\mathrm{Ni}$ that results in suppression of helium bubbles nucleation and growth (Fig. 4).

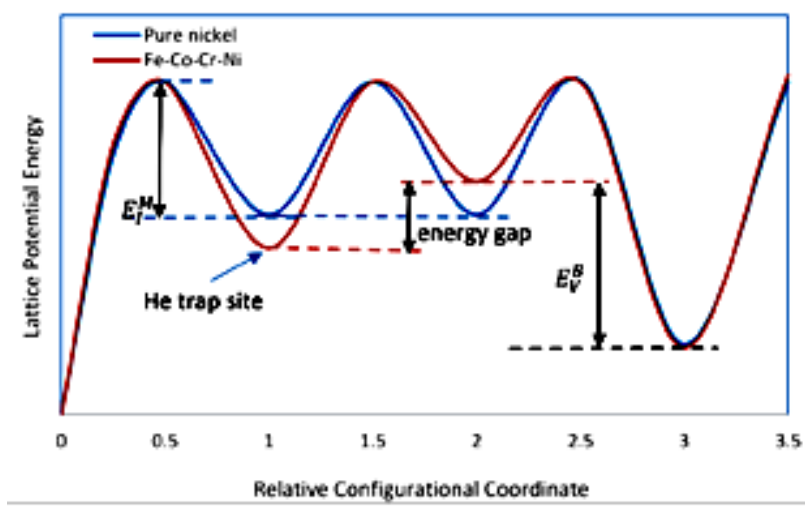

Fig. 4. Schematic diagram of the fluctuation of lattice potential energy in $\mathrm{Fe}-\mathrm{Co}-\mathrm{Cr}$-Ni alloy and pure nickel. $\boldsymbol{E}_{\boldsymbol{I}}{ }^{\boldsymbol{M}}$ and $\boldsymbol{E}_{\boldsymbol{V}}{ }^{\boldsymbol{B}}$ are migration energy of interstitial He and binding energy between He atom and vacancy, respectively [13] 
As follows from Fig. 4, interstitial migration is strongly controlled by the migration energy of interstitial $\mathrm{He}, \boldsymbol{E}_{\boldsymbol{I}}{ }^{\boldsymbol{M}}$, since $\mathrm{He}$ atoms can migrate via jumps between different interstitial positions [14].

In the case of vacancy migration mechanism, the binding energy between He atom and vacancy, $\boldsymbol{E}_{\boldsymbol{V}}{ }^{\boldsymbol{B}}$, will primarily govern migration process.

Helium atoms injected into the lattice upon irradiation migrate through interstitial positions before trapping and agglomerating with vacancies (see Fig. 4).

Tsai et al. $[8,15]$ have studied kinetics of diffusion of $\mathrm{Co}, \mathrm{Cr}, \mathrm{Fe}, \mathrm{Mn}$, and $\mathrm{Ni}$ in high entropy alloy by using the method of diffusion couple. They founded that the diffusion coefficients are lower in HEA compared to conventional metals. Large fluctuations of lattice potential energy in $\mathrm{Co}-\mathrm{Cr}-\mathrm{Fe}-\mathrm{Mn}-\mathrm{Ni}$ facilitate the formation of deeper traps and atomic blocks resulted in high activation energy and low diffusion mobility of atoms.

Despite a discrepancy between regular atomic diffusion and interstitial $\mathrm{He}$ diffusion due to its low solubility and ability to form bubbles, the effect of sluggish diffusion can be used to explain the differences in the behavior of $\mathrm{He}$ in $\mathrm{Fe}-\mathrm{Co}-\mathrm{Cr}-\mathrm{Ni}$ equiatomic alloy and steel.

It was suggested in [14] that due to the considerable lattice distortion, the potential energy gap between two adjacent positions in the $\mathrm{Fe}-\mathrm{Co}-\mathrm{Cr}-\mathrm{Ni}$ lattice is rather large relative to the ideal zero in pure nickel, as injected $\mathrm{He}$ atoms in $\mathrm{Fe}-\mathrm{Co}-\mathrm{Cr}-\mathrm{Ni}$ are influenced by severe fluctuations in the lattice potential energy during frequent jumps in the process of diffusion and the formation of clusters. As a result, a larger number of helium atoms may be captured by traps with low potential energy (shown by the blue arrow in Fig. 4). Due to difficult migration of He atoms, the formation of helium bubbles is retarded in HEA, wherefore Fe-Co$\mathrm{Cr}-\mathrm{Ni}$ has a much higher critical $\mathrm{He}$ concentration needed to detect TEM-visible helium bubbles at room temperature.

Frenkel pairs will be generated in a cascade of defects due to ion irradiation of both $\mathrm{CrFeMnNi} \mathrm{HEA}$ and steel. As has been demonstrated in [16], upon the cooling down of the ballistic phase ( 0.5 picosecond) of the damage cascade, defect recombination will take place during the kinetic phase within a picosecond. The number of defects that will survive in this case is $\approx 30 \%$ for metals [17, 18]. The processes of generation and recombination of defects caused by irradiation have a nanosecond time scale [19], while sluggish diffusion and evolution of defects may continue microseconds in HEAs [20].

Y.N. Osetsky et al. [20] believe that the physical origin of the sluggish diffusion effect may be attributed to the compositional dependence of vacancy migration energy with maximum near the site percolation threshold, and argued that the coupled percolation and composition-dependent barriers for vacancy jumps within different subsystems in HEA leads to the sluggish diffusion.

Implanted helium atoms located in interstitial positions will ultimately recombine with surviving defects, leading to the bubble's nucleation throughout the irradiated layer. The lower helium swelling in HEA compared to steel, observed in this study, indicates that the mechanism of inert gas bubble growth in HEA can be suppressed.

\section{CONCLUSION}

The microstructure evolution in Cr-Fe-Ni-Mn highentropy alloy and $18 \mathrm{Cr} 10 \mathrm{NiTi}$ stainless steel after irradiation with helium ions to $4.8 \mathrm{dpa}$ and 11.7 at.\% at room temperature and post-irradiation annealing was investigated.

Irradiation promoted the formation of a high density of bubbles in HEA and steel. Comparison of the parameters of helium porosity in these materials showed that the swelling in CrFeNiMn alloy is about two times smaller than that in $18 \mathrm{Cr} 10 \mathrm{NiTi}$ steel.

The obtained result indicates that CrFeNiMn is much more resistant to the formation of helium bubbles than conventional $18 \mathrm{Cr} 10 \mathrm{NiTi}$ stainless steel.

\section{REFERENCES}

1. S.J. Zinkle, J.T. Busby. Structural materials for fission \& fusion energy // Mater. Today. 2009, v. 12, N 11, p. 12-19.

2. H. Ullmaier. The influence of helium on the bulk properties of fusion reactor structural materials // Nucl. Fusion. 1984, v. 24, N 8, p. 1039-1065.

3. S. Sharafat, A. Takahashi, Q. Hu, et al. A description of bubble growth and gas release of helium implanted tungsten // J. Nucl. Mater. 2009, v. 386-88, p. 900-903.

4. G.M. McCracken. The behaviour of surfaces under ion bombardment // Rep. Prog. Phys. 1975, v. 38(2), p. 241-325.

5. J.W. Yeh, S.K. Chen, S.J. Lin, J.Y. Gan, T.S. Chin, T.T. Shun, C.H. Tsau, S.Y. Chang. Nanostructured High-Entropy Alloys with Multiple Principal Elements: Novel Alloy Design Concepts and Outcomes // Adv. Eng Mater. 2004, v. 6(5), p. 299-303.

6. Y. Zhang, T.T. Zuo, Z. Tang, M.C. Gao, K.A. Dahmen, P.K. Liaw, Z.P. Lu. Microstructures and properties of high-entropy alloys // Prog Mater Sci. 2014, v. 61, p. 1-93.

7. D.B. Miracle, O.N. Senkov. A critical review of high entropy alloys and related concepts // Acta Materialia. 2017, v. 122, p. 448-511.

8. Ming-Hung Tsai \& Jien-Wei Yeh. High-Entropy Alloys: A Critical Review // Mater. Res. Lett., 2014, v. 2, N 3, p. 107-123.

9. М.А. Тихоновский, А.С. Тортика, И.В. Колодий, П.И. Стоев, Т.Ю. Рудычева, Н.С. Бережная, И.Г. Танцюра, З.И. Колупаева, И.К. Мельников. Микроструктура и свойства высокоэнтропийных сплавов $\quad \mathrm{CoCrFeMnNiV}_{0,25} \mathrm{C}_{0,175}$ и $\mathrm{CrFe}_{2} \mathrm{MnNiV}_{0,25} \mathrm{C}_{0,175} / /$ Bопросы атомной науки $u$ техники. Серия "Физика радиационных материалов и радиациионное материаловедение». 2016, №4(104), c. $37-41$.

10. G.D. Tolstolutskaya, V.V. Ruzhytskiy, I.E. Kopanetz, V.N. Voyevodin, A.V. Nikitin, S.A. Karpov, A.A. Makienko, T.M. Slusarenko. Accelerating complex for study of helium and hydrogen behavior in conditions of radiation defects generation // Problems of Atomic Science and Technology. Series 
"Physics of Radiation Effect and Radiation Materials Science”. 2010, N 1, p. 135-140.

11. http://www.srim.org/

12. ASTM E521-96, 2009, ASTM.

13. V.V. Ruzhytskyi, S.A. Karpov, A.S. Kalchenko, I.E. Kopanets, B.S. Sungurov, G.D. Tolstolutskaya. Helium porosity development during annealing of helium- implanted 18Cr10NiTi steel // East European Journal of Physics. 2018, v. 5, N 4, p. 28-35.

14. Yan Zhanfeng, Liu Shaoshuai, Xia Songqin, Yong Zhang, Yugang Wang, Tengfei Yang. He behavior in $\mathrm{Ni}$ and $\mathrm{Ni}$-based equiatomic solid solution alloy // J. Nucl. Mater. 2018, v. 505, p. 200-206.

15. K.-Y. Tsai, M.-H. Tsai, J.-W. Yeh. Sluggish diffusion in $\mathrm{Co}-\mathrm{Cr}-\mathrm{Fe}-\mathrm{Mn}-\mathrm{Ni}$ high-entropy alloys // Acta Materialia. 2013, v. 61, p. 4887-4897.

16. Y. Zhang, S. Zhao, W. J. Weber, K. Nordlund, F. Granberg, F. Djurabekova. Atomic-level heterogeneity and defect dynamics in concentrated solid-solution alloys // Current Opinion in Solid State and Materials Science. 2017, v. 21(5), p. 221-237.

17. A. Calder, D. Bacon. A molecular dynamics study of displacement cascades in alpha-iron // J. Nucl. Mater. 1993, v. 207, p. 25-45.

18. J.B. Gibson, A.N. Goland, M. Milgram, G.H. Vineyard. Dynamics of radiation damage // Phys. Rev. 1960, v. 120, p. 1229-1253.

19. B. Wirth, G. Odette, J. Marian, L. Ventelon, J. Young-Vandersall, L. Zepeda-Ruiz. Multiscale modeling of radiation damage in Fe-based alloys in the fusion environment // J. Nucl. Mater. 2004, v. 329-333, p. 103-111.

20. Y.N. Osetsky, L.K. B'eland, A.V. Barashev, Y. Zhang. On the existence and origin of sluggish diffusion in chemically disordered concentrated alloys // Current Opinion in Solid State and Materials Science. 2018, v. 22(3), p. 65-74.

\title{
СРАВНИТЕЛЬНОЕ ИССЛЕДОВАНИЕ РАЗВИТИЯ ГЕЛИЕВЫХ ПУЗЫРЬКОВ В Cr-Fe-Ni-Mn ВЫСОКОЭНТРОПИЙНОМ СПЛАВЕ И СТАЛИ Х18Н10Т ПОСЛЕ ОБЛУЧЕНИЯ И ПОСТРАДИАЦИОННОГО ОТЖИГА
}

\author{
А.С. Кальченко, С.А. Карпов, И.Е. Копанец, М.А. Тихоновский, Г.Д. Толстолуцкая
}

Высокоэнтропийные сплавы (ВЭС) рассматриваются как перспективные материалы для применения в ядерных реакторах из-за их многообещающих механических свойств, коррозионной и радиационной стойкости. С целью понимания влияния облучения на свойства ВЭС и демонстрации их потенциальных преимуществ по сравнению с обычными аустенитными нержавеющими сталями мы провели эксперименты по облучению в идентичных условиях ионами гелия с энергией 20 кэВ ВЭС 20Cr-40Fe-20Ni-20Mn и стали X18H10T. Оба сплава были облучены при комнатной температуре до дозы 4,8 смещения на атом (сна) и концентрации гелия 11,7 ат.\%. Эволюцию микроструктуры облученных материалов исследовали после отжига при $500{ }^{\circ} \mathrm{C}$. Облучение и отжиг привели к образованию высокой плотности пузырьков в ВЭС и стали. Проведено сравнение параметров гелиевой пористости в этих материалах.

\section{ПОРІВНЯЛЬНЕ ДОСЛІДЖЕННЯ РОЗВИТКУ ГЕЛІЄВИХ БУЛЬБАШОК У Cr-Fe-Ni-Mn ВИСОКОЕНТРОПІЙНОМУ СПЛАВІ І СТАЛІ Х18Н10Т ПІСЛЯ ОПРОМІНЕННЯ І ПОСТРАДІАЦІЙНОГО ВІДПАЛУ}

\author{
О.С. Кальченко, С.О. Карпов, І.С. Копанець, М.А. Тихоновський, Г.Д. Толстолуцька
}

Високоентропійні сплави (ВЕС) розглядаються як перспективні матеріали для застосування в ядерних реакторах через їх багатообіцяючі механічні властивості, корозійну та радіаційну стійкість. 3 метою розуміння впливу опромінення на властивості ВЕС і демонстрації їх потенційних переваг у порівнянні зі звичайними аустенітними нержавіючими сталями ми провели експерименти з опромінення в ідентичних умовах іонами гелію 3 енергією 20 кеВ BEC 20Cr-40Fe-20Ni-20Mn i стали X18Н10Т. Сплави були опромінені при кімнатній температурі до дози 4,8 зміщення на атом (зна) і концентрації гелію 11,7 ат.\%. Еволюцію мікроструктури опромінених матеріалів досліджували після відпалу при $500{ }^{\circ} \mathrm{C}$. Опромінення і відпал призвели до створення високої щільності бульбашок у ВЕС і сталі. Проведено порівняння параметрів гелієвої пористості в цих матеріалах. 